Удк 378:930.25

DOI: $10.30914 / 2227-6874-2018-11-140-151$

\title{
Contemporary challenges in archival science and possible guidelines for universities to confront them
}

\author{
Aida Škoro Babić
}

\begin{abstract}
The aspect of archival science as a scientific discipline is quite young compared to other scientific disciplines. The field of the archival science education was not systematically regulated in Slovenia, since the study of archival science at the public university was not established. Knowledge of what is necessary in the elaboration of the device to emphasize, archivists usually acquire with longstanding work in archives and in direct contact with users. By analysing the current needs and issues "on the field" at records creation in this paper the author will compare those results to results of analysis of educational program of archival science and records management in Slovenia, as well as further orientations for improving it. The article attempts to determine how satisfactory is the approach of pedagogical process to fulfil the knowledge gap of archival records creators and archives.
\end{abstract}

Keywords: archival science, archives, archival education, archival knowledge, university.

Citation for an article: Aida Škoro Babić. Contemporary challenges in archival science and possible guidelines for universities to confront them. West - East. 2018, no. 11, pp. 140-151. DOI: 10.30914/2227-6874-2018-11-140-151

Archival science is deeply involved in the records management. Especially in the field of digitization, digitalization and electronic records management systems. There is an increasing need for a profile that will include the knowledge of basic archival principles as a modern information technology, thus providing comprehensive knowledge.

Archival records creators are facing the obligation to preserve records in a way so they remain authentic and integral and the obligation to prepare those records for transfer to public archives. There are many issues, which both, archives and records creators are dealing in practice, and there is a huge need to establish best theory to perform in practice. There are currently many challenges in archival science, among which are the most current issues of electronic material due to the risk of loss of data or the creation of permanent conservation. 
By analysing the current needs and issues "on the field" at records creators based on the work of National archives we made the comparison of those results of analysis of educational program of archival science and records management in Slovenia, as well as further orientations for improving it. Our attempt is to determine how satisfactory is the approach of pedagogical process to fulfil the knowledge gap of archival records creators and archives.

\section{Archival science as a scholar discipline - science}

Rectors of European universities gathered in Bologna at the 900th anniversary of the oldest university among them, agreed that cultural, scientific and technical development, on which the future of humankind depends largely, is created in the centres of culture, knowledge and research. The cultural, social and economic future requires considerable efforts for continuous education. This conclusion is in any case, based on the long history of human existence, which originated from reason through the spiritual foundations of the enlightenment, enlightened absolutism, the bourgeois revolution in France, the birth of nationalism, resulting in the development of science. We need to agree with Prunk who says that the man of European civilization, who developed at least 2500 years ago, is not content only with material goods, but also searches for spiritual ones, and asks about the meaning of his existence and looks for his happiness [15, p. 67]. In this concluding thought, we can find a cue on the need and importance of education in individual fields, especially of those, that were not systematically regulated.

The field of the archival science education was not systematically regulated in Slovenia, since the study of archival science at the public university was not established - but only on private one. ${ }^{1}$

The question, which is very important for pedagogical process regarding archival science, is, whether it is a science at all. Archival science is the foundation for professionalism and the research in archival science, which is a precondition for a successful development of the profession. That is why archival science must not obtain merely the status of auxiliary science. Academic freedom requires independence of academic teaching and studying without outdoor political interference and is essential for every science [14, p. 128].

The aspect of archival science as a scientific discipline is quite young compared to other scientific disciplines. Other scientific sciences developed well, if not earlier, at least at the end of the 19th century, when human civilization confronted the achievements of natural sciences in the fields of physics,

\footnotetext{
${ }^{1}$ On public universities in Slovenia archival science is introduced only as an auxiliary science of historiography - in the framework of the study of history. Private university from Maribor (Alma Mater Europaea) in 2012/2013 introduced Master study of Archival science and records management.
} 
chemistry, biology, technology, and in the field of social sciences and humanities, with the advancement of historical science, philosophy and sociology. The need to understand archival science, not only from a practical point of view, but also from a theoretical point of view, has emerged through the 20th century $[9 ; 8]{ }^{1}$ Various experts in the field of archival science mediated it, first through the delimitation of the archival and library profession, and in Slovenia, in particular, through the delimitation of the archival and museum profession. In today's society, we are mainly facing the misunderstanding on the issue what are archival records and what or who are archivists. The society is dominated by the thought that the archives are warehouses of the old paper, the museums of documents, collectors of past attractions, and archivists guardians of dusty, dead records. But the matter is much more complex and much more up-to-date, as the accidents that we have seen in newspaper publications are warned against. ${ }^{2}$ Archival material is particularly important for the protection of the rights of man and citizen. Archives were created precisely because of legal needs and property protection.

The practice of archival administration grew in Europe as soon as the practice of writing on perishable materials was invented. Ancient Greece and the Roman Empire had archival repositories. The period of Roman Empire is actually the starting point for every study of European legal, political, and cultural history. All these archives were destroyed during the Great Invasions of the fifth, sixth, and seventh centuries, but the practice of archiving in Europe remained. ${ }^{3}$ Thus we have rich collections of royal, municipal and church archives from the $13^{\text {th }}$ century. After the French revolution, when modern archives emerged, collections of archival records became even more rich and diverse. Schellenberg is asking the question, what reasons led France, England and the United States to establish archival institutions and then he is answering it with: the obviously the most impelling reason was the practical need of improving governmental efficiency $[17$, p. 4]. We can surely agree that, archival records are documents that have a lasting importance for the legal interest of legal and natural persons or a permanent significance for history, other sciences and culture. This is also the definition of archival records in Slovenian archival law (ZVDAGA, 2014).

\footnotetext{
${ }^{1}$ Duranti had been discussing about the nature archival education and been using the term archivology.

${ }^{2}$ In last few years we have been witnessing the issue of losing or destroying archival records in different countries. Among them were also important governmental records. If we just mention some of those cases: more than 400 documents missing in British National Archives (BBC, 3.8.2016: https://www.bbc.com/news/uk-politics-36953199), British government admitted losing thousants of papers from National Archives (The Guardian, 26.12.2017: https://www.theguardian.com/uknews/2017/dec/26/government-admits-losing-thousands-of-papers-from-national-archives)

${ }^{3}$ Michel Duchein is giving the brief overview of the history of European archiving in The History of European Archives and the Development of the Archival Profession in Europe (1992).
} 
With other words, archival material justifies the identity of the community and the individual. In doing so, it is necessary to ask which documents are important and what makes them important, and we must ask ourselves who can accurately evaluate the importance of the document. Very important is the understanding of the development of the importance of legal and informational value of archival records. Cook was dealing with the issue of informational value in From Information to Knowledge: An Intellectual Paradigm for Archives, Archivaria 19, Winter 1984-85, p. 42-44. Through case studies it is necessary to understand what is the legal and what is the informational value and what crucial conditions are necessary for retaining the legal and informational value.

Thus, the core of archival science is the determination of value, which is not merely the assessment of the value of material interesting only to scientists and other researchers of the past, but the importance of a document that must be permanently preserved and made available for use.

If we want to recognize archival science as a science, it should be composed of theory and the methodology $[9$, p. 10]. If we look closer, archival science is composed of theory and methodology, and both are implemented in practical work of archivists. So, if we want science to get developed into science, scholar approach is necessary and thus the archival education. Eastwood made a nice observation of educational issue in archival science already in 1988, when the issue of archival education in the United States was very actual. His final conclusion was, that the only place for archival education is university [10, p. 251].

In Slovenia, the issue of archives and archival education emerged mainly after 1945 and was triggered by historians who, at their assembly in 1946, dealt with the topic of acquisition of archival records and the issue of material protection. In the fifties at the national level, they considered to establish a suitable archival school but this never happened [14]. The development of the archival science in the international context caused the archivist's introduction into the curriculum of the Department of History at the Faculty of Arts in Ljubljana in the academic year 1978/79 [24]. Archival science was held in Ljubljana and later in other Slovenian universities, as in many world universities, only as auxiliary historical science [18]. In the global context, the regulation of archival science studies has begun to be regulated several decades ago, especially in the framework of studies in librarianship, and increasingly in information science. How serious was the issue of archival science in addition to professionally established archives in the first half of the 20th century is also shown by the establishment of the International Archives Council in Paris in 1948 and two years later, also in Paris, the first archival congress [14]. The severity of archival issues triggered the need for systematic education in the field of archival science. 
Gilliland observed the development of studies programs and concluded that all those professional programs, related to archival science, began to diversify from the mid-1990s and converge with computer science, management, communication, business and digital humanities programs and later to informational studies programs $[11$, p. 46]. In this observation Gilliland set the conclusion that archival and recordkeeping studies programs and departments within the academy largely focus on preparing professionals for archival and recordkeeping careers, and increasingly on doctoral education which will prepare future academics and research-in-practice [11, p. 47].

\section{Knowledge to be gained}

Tasks of archives and archivists include:

- registering, collecting and processing of archival material; compilation of archival guides, inventories and other finding aids;

- keeping of registers of public and private records created by legal and natural persons;

- management of a computer-based information system for the archives;

- appraisal of records created by entities under the public law and professional supervision thereof;

- training of documentation records managers;

- cooperation with the owners of private records, consultancy and supervision;

- custody and preservation of archival material;

- conservation, restoration and reproduction (microfilming and scanning) of records for security purposes;

- compilation of finding aids and guides to foreign records, and reproduction of such records to supplement the Archives' holdings;

- publishing of archival sources which are kept in the Archives and in foreign archives and are of significance to the history of the nation;

- making archival material available for use, issuing transcripts and copies of archival documents as well as certificates based on archival documents;

- cultural activities, education and training related to archival material;

- research in archival science, history and other related disciplines;

- publishing activities;

- organisation and co-ordination of matters and procedures in archival service (Archival Centre for Professional Development);

- tasks of common significance for records preservation of the state. ${ }^{1}$

\footnotetext{
${ }^{1}$ All those tasks are common to all archives, but this list was made according to tasks, published on the web site of teh Archives of the Republic of Slovenia: http:/www.arhiv.gov.si/en/about the_archives/ tasks_and_objectives/ (taken on 27.11.2018).
} 
For the recording, collection and professional processing of archives, it is necessary to examine the material and the creator of the material, or the circumstances of the creation, as well as the contents of the material. This is a place where knowledge of history is most welcome - for easier management of longer and shorter time zones, institutional structures, administrative and legal arrangements, different languages and fonts, etc. It is necessary to know the time and space in which the material was created, as well as to identify key questions that would be of interest to the user, because in professional processing the documents are written in a way that they approach the user in a substantive manner. It is also desirable and necessary for archivists to monitor the trends of research, since only in this way they can successfully assist the researcher. This is especially important in the production of materials for the examination of materials, for inventories and inventories, and for the descriptor input, which greatly facilitates the researcher to penetrate through a meter of written material. Knowledge of what is necessary in the elaboration of the device to emphasize, archivists usually acquire with long-standing work in archives and in direct contact with users.

Creators of archival records are facing the obligation to preserve records in a way so they remain authentic and integral and the obligation to prepare those records for transfer to public archives. There are many issues, which both, archives and records creators, are dealing in practice, and there is a huge need to establish best theory to be performed in practice. There are currently many challenges in archival science, among which are the most current issues of electronic material due to the risk of loss of data or the creation of permanent conservation.

Archival records are those records that have a lasting importance for the legal interest of legal and natural persons or a permanent significance for history, other sciences and culture ${ }^{1}$, in other words, archival records justify the identity of the community and the individual. In doing so, it is necessary to ask which documents are important and what makes them important, and we must ask ourselves who can accurately evaluate the importance of the document. The goals of pedagogical process should be: understanding the development of the importance of legal and informational value of archival records. Through case studies to understand what is the legal and what is the informational value. To understand what crucial conditions are necessary for retaining the legal and informational value. Thus, the core of archival science is the determination of value, which is not merely the assessment of the value of material interesting only to scientists and other researchers of the past, but the importance of a document that must be permanently preserved and made available for use.

\footnotetext{
${ }^{1}$ Slovenian Archival Law (ZVDAGA, 2014).
} 
In order to ensure that the protection of these documents and in order to keep the documents not only preserved, but also accessible, it is necessary to take care of the creation of documents, and this task requires the establishment of effective education. If we want to keep legal and informational value, several conditions are necessary. The important condition is a fair and professional appraisal. The same record can contribute necessary data in different time and place and for different individuals. But the duty and task of archives is not to judge, but rather to preserve those documents and to make them accessible, when necessary - archives have a crucial role in the truth-seeking process [20, p. 42]. Political systems and state regulations have changed over the course of history. What used to be right was later recognized as wrong. What was once punished was later recognized as innocent. The same archival document can be charging at some point, at another can be liberating [19, p. 182]. Cook gave an important point here: "Can one really believe that archivists hired by and under the control of the FBI or the RCMP will preserve a neutral, disinterested archival record? If Richard Nixon had hired his own archivists to conserve his tapes and records in some hypothetical White House Archives, can anyone believe that the result would be the same as under the neutral control of the National Archives and Records Administration?" [6, p. 31].

The main core of archival work is a document/ a record. The challenge ahead of archival science is to determine the definition of the document, of the record, of the attachment in electronic record management system - which can be a record or the appendix of the record.

Archivists must identify key issues in which users might be interested in order to ensure that the documents are described in such a way that their content and importance is aligned with anticipated user needs and that keeps the context, which is giving it an evidential value.

Effective protection for data archives is necessary if the archives wants to remain a safe and trustful repository of the most important records: with regard to the definition of sensitive data, which need to be protect and in respect of periods of availability. European regulation on data protection made a huge dilemma on dealing with records [6, p. 31].

Archives need to build the trust of the general public about protection the data of individuals and about preventing abuses. Special knowledge on legal regulations are thus necessary.

Record in context is the records with value. Record without a context does not have any value. Placing the record in context (in describing it or in the search for it) requires knowledge of the society, political systems, changing state borders, knowledge on the cultural history - depends on the period that we are covering (I guess we can't know all). But they need to have a solid sense of track of time, which is closely connected to: 
- what materials were produced in specific times (timelines of types of paper, software...),

- what ink was produced in specific times,

- what script was used in specific time and/in specific area,

- what language was used in specific time and/ in specific area,

- what kind of political system was, with what kind of institutions ...,

- ethnical borders...,

- main time turning points,

- key figures of the time and the specific area,

- legal basis of the establishment of institution: which are key institutions in certain time and/or specific area, where to find them: why some institutions were founded at specific time. ${ }^{1}$

The legal value and informational value are closely connected to appraisal. If appraisal and after that the transmission is not done properly, the record loses its value. How to ensure testimonial value of records? By getting to know the functioning of the institution, by getting to know the legal basis of the establishment of institution: where to find them: why some institutions were founded at specific time; what was their purpose and what were relations at the time, by getting to know record management system of the institutions, by getting to know the working process of the institution its purpose and what were relations at the time. Knowing that, the testimonial value is preserved (legal value).

Since the present time is giving archival science many challenges, it is impossible to overlook electronic records. In electronic environment to preserve the legal value, certain requirements must be fulfilled. The fundamental requirements of electronic transactions are no different in their basic nature from their paper counterparts. They need to be recorded, captured in a fix form, maintained and made accessible as records. But there is a additional need to understand the relationship between the metadata and the record. ${ }^{2}$

\footnotetext{
${ }^{1}$ Caswell, Broman, Kirmer, Martin, Sowry (2012) report on three class exercises from an introductory archives course offered by the School of Library and Information Studies at the University of Wisconsin-Madison, where students are trained to read archival records "along the grain" to uncover the intentions of their creators, revealing the anxieties and uncertainties associated with the maintenance of Power and in the ways in which power is made manifest by both the creation of records and their archivization with the possibility to open them up to the possibility of hearing the voices of the marginalized in the records [5].

${ }^{2}$ Related to the connection between metadata and the record Wood, Carbone, Cifor, Gilliland, Punzalan (2014) were discussing issues of describing voluminous records, related to the need of exposing the evidential as well as the informational value of these materials in ways that will support both foreseen and unforeseen uses and users into an infinite future. There are several studies related to the provenance metadata, see Bose and Frew (2005) [3], Bowers and al. (2006) [4], Heinis (2008) [12].
} 
The role of archivists is necessary in control the formation and creation of digital preservation, planning substantive classification of material in the control of any substantive changes in the capture and conversion of material, and of course in the appraisal of the electronic records. Archivists need to be able to recognize basics in term to recognize the abuse or hiding records. ${ }^{1}$

\section{Conclusion}

Archival fonds and functions now span nations and are subject to various national and international legislation, treaties and archival practices and for understanding these issues is important to understand the full complexity of the provenance of the archival record.

In an archival context a record is authentic when it is what it claims to be. The truthfulness of the content of the record is irrelevant for the concept of authenticity. Important is the concept of reliability. The goal is that the user is sure that records in archives are reliable and authentic.

Concept of authenticity is closely connected to the trust and trustworthiness. And this is connected to contextual properties. ISO 15489 defined that the authentic record is one that can be proven: to be what it purports to be, to have been created or sent by the persons purported to have created or send it, to have been created or sent at the time purported. ${ }^{2}$

The important need that was shown in the analysis is that records creators need help in creating adequate classification scheme/plan for their records. Uniform classification plan/scheme is shown to be not the best practice - it can not suit to every record creator (since the function of classification scheme is valued by the possibility of finding records) - the task of study program is to resolve the issue of relations between the original order and final placement of records according to classification plan.

Special attention must be given to hybrid records - where is the biggest chance to lose an original and to replace it with the forgery. Based on the analysis made in the governmental and judiciary institutions of Slovenia, electronic record management was introduced almost in all areas. Hybrid records management system is present especially in government, public administration and judiciary. ${ }^{3}$

The challenges of the further development of the e-archives also open the door to the new profiles of archivists in the future, as applicative research in the field of infrastructure improvements will be necessary for future development. Educational study program of archival science should keep track of practical work

\footnotetext{
${ }^{1}$ In important study on Educating for Tust see Duranti and Rogers (2011) [9].

${ }^{2}$ ISO 15489:2001.

${ }^{3}$ This topic was introduced by Škoro Babić at VNIIDAD conference in Moscow 21.-24.11.2017 with Hybrid records.
} 
of archives and should set the theory, which could be introduced into practice. Archival science thus must be recognized as applied science with affective results of the scholar research with the well established terminology.

In order to ensure that the protection of these documents is kept smoothly in order to keep the documents not only preserved, but also accessible, it is necessary to take care of the creation of documents, and this task requires the establishment of effective education.

\section{References}

1. Archive of the Republic of Slovenia, www.ars.gov.si (http://www.arhiv.gov.si/en/ about_the_archives/tasks_and_objectives) (accessed 27.11.2018).

2. BBC, 3.8.2016. Available at: https://www.bbc.com/news/uk-politics-36953199 (accessed 27.11.2018).

3. Bose R, Frew J (2005) Lineage retrieval for scientific data processing: a survey. ACM Comput Surv 37(1), pp. 1-28. Available at: https://dl.acm.org/citation.cfm?doid=1057977.1057978 (accessed 27.11.2018).

4. Bowers S., McPhillips T., Ludäscher B., Cohen S., Davidson S. B. (2006) A model for useroriented data provenance in pipelined scientific workflows. Proceedings of the International Provenance and Annotation Workshop. Available at: http://repository.upenn.edu/cis_papers/290/ (accessed 10.12.2018).

5. Caswell M., Broman G., Kirmer J., Martin L., Sowry N. (2012) Implementing a social justice framework in an introduction to archives course: lessons from both sides of the classroom. InterActions UCLA J Educ Inf Stud 8(2). Available at: https://escholarship.org/uc/item/2jx083hr (accessed 27.11.2018).

6. Cook T.: in From Information to Knowledge: An Intellectual Paradigm for Archives, Archivaria 19, Winter 1984-85, pp. 28-49.

7. Duchein M. (1992). The History of European Archives and the Development of the Archival Profession in Europe. American Archivist, vol. 55, Winter 1992, pp. 1-25.

8. Duranti L. (1993). The Archival Body of Knowledge: Archival Theory, Method, and Practice and Graduate and Continuing Education. Journal od Education for Library and Information Science, Vol. 34, No 1 (Winter 1993), pp. 8-25.

9. Duranti L., Rogers C.: Educating for Trust. Archival Science, (2011) 11. pp. 373-390.

10. Eastwood T.: Nuturing Archival Education in the University. American Archivist, Vol. 51, Summer 1988, pp. 228-252.

11. Gilliland A. J. (2017): Archival and Recordkeeping Traditions in the Multiverse and their Importance for Researching Situatuons and Situating Research. Research in the Archival Multiverse, Monash University, 2017. pp. 31-73. Available at: file:///C:/Users/skoro/Downloads/628143.pdf (accessed 30.11.2018).

12. Heinis T, Alonso G (2008) Efficient lineage tracking for scientific workflows. In: Proceedings of the 2006 ACM SIGMOD International Conference on Management of Data. Available at: https://dl.acm.org/citation.cfm?doid=1376616.1376716 (accessed 10.12.2018). ISO 15489:2001

13. Magna Charta Of European Universities. Bologna, September 1988.

14. Melik Jelka, Jeraj, Mateja (2013). Začetki poti slovenske arhivistike v drugi polovici dvajsetega stoletja. Atlanti 23. Pp. 111-119.

15. Prunk, Janko (2003), Zgodovina in perspektiva konstitutivnih idej evropske racionalistične civilizacije 1775-2000. Dignitas, 17-18, pp. 3-68. 
16. The Guardian, 27.11.2018: https:/www.theguardian.com/uk-news/2017/dec/26/governmentadmits-losing-thousands-of-papers-from-national-archives (accessed 20.11.2018).

17. Schellenberg T.R. (2003), Modern Archives: Principles and Techniques (Chicago: University of Chicago Press) 2003. Available at: http://files.archivists.org/pubs/free/ModernArchivesSchellenberg.pdf (accessed 20.11.2018).

18. Semlič Rajh Z., Škoro Babić A. (2015): Arhivist, quo vadis? Arhivi na razpotju. Ptuj 2015, pp. 121-129.

19. Škoro Babić A. (2016): Uspešna in učinkovita zaščita podatkov: mit ali uresničljiva naloga? Atlanti, 26, 2016, n. 1, p. 182.

20. Škoro Babić A. (2017): A Case Study in Access to the Archival Records of the Military Courts of the Former Yugoslavia. Emerging Trends in Archival Science, 2017, pp. 27-50.

21. Škoro Babić A. (2017): Hybrid Records, VNIIDAD conference in Moscow 21.-24.11.2017.

22. Wood S., Carbone K., Cifor, Gilliland A., Punzalan R. (2014): Mobilizing records: re-framing archival description to support human rights. Archival Science (2014) 14. Pp. 397-419.

23. Zakon o varstvu dokumentarnega in arhivskega gradiva ter arhivih (ZVDAGA) (Ur. 1. RS, št. 30/2006, 24/2014. Odl. US in 51/2014) (Slovenian Archival Law).

24. Žontar J. (1995): Zgodovina arhivistike na Slovenskem. Arhivi. 1995, pp. 13-17.

Submitted 28.11.2018; revised 10.12.2018.

The author has read and approved the final manuscript.

\section{About the author}

\section{Aida Škoro Babić}

MPhil, Ministry of Culture, Archives of the Republic of Slovenia, Senior Adviser - Archivist; Alma Mater Europaea - European Centre Maribor, Department for archival Science and Records Management, Senior Lecturer, aida.skoro@gov.si, aida.s.babic@gmail.com

\section{Современные вызовы в архивоведении и возможные рекомендации университетам по их решению}

\section{Аида Шкоро Бабич}

Архивоведение как научная дисциплина достаточно молода по сравнению с другими научными дисциплинами. В Словении сфера архивного образования не имела систематического регулирования, поскольку изучение архивоведения в государственных университетах не велось. Знания о том, чему необходимо придавать особое значение, архивисты обычно приобретают при многолетней работе в архивах и в непосредственном контакте с пользователями. Анализируя текущие потребности и проблемы "на местах" при создании документации, автор сопоставит полученные результаты с результатами анализа образовательной программы архивоведения и делопроизводства в Словении, а также дальнейшие направления ее совершенствования. В статье предпринята попытка определить, насколько 
удовлетворительным является подход педагогического процесса к восполнению пробелов в знаниях создателей архивных документов и архивов.

Ключевые слова: архивоведение, архивы, архивное образование, архивные знания, университет.

Для цитирования: Аида Шкоро Бабич. Современные вызовы в архивоведении и возможные рекомендации университетам по их решению // Запад - Восток. 2018. № 11. C. 140-151. DOI: 10.30914/2227-6874-201811-140-151

Статья поступила в редакиию 28.11.2018 г.; принята к публикации 10.12.2018 г. Автор прочитал и одобрил окончательный вариант рукописи.

\section{Об авторе}

\section{Шкоро Бабич Аида}

старший архивист, Министерство культуры, Архивы Республики Словения; старший преподаватель кафедры управления архивным делом и делопроизводством, факультета архивоведения, Европейская академия наук, Европейский центр Марибор,aida.skoro@gov.si,aida.s.babic@gmail.com 